\title{
A FUZZY DECISION-MAKING APPROACH FOR PORTFOLIO MANAGEMENT WITH DIRECT REAL ESTATE INVESTMENT
}

\author{
Eddie Chi Man HUI ${ }^{1} \bowtie$, Otto Muk Fai LAU ${ }^{2}$ and Kak Keung LO ${ }^{3}$ \\ ${ }^{1}$ Department of Building and Real Estate, The Hong Kong Polytechnic University, Hung Hom, \\ Kowloon, Hong Kong \\ E-mail: bscmhui@inet.polyu.edu.hk \\ 2 Department of Building and Real Estate, The Hong Kong Polytechnic University, Hung Hom, \\ Kowloon, Hong Kong \\ E-mail: nokia_rokia@hotmail.com \\ 3 Department of Building and Real Estate, The Hong Kong Polytechnic University, Hung Hom, \\ Kowloon, Hong Kong \\ E-mail: bskklo@inet.polyu.edu.hk
}

Received 18 February 2009; accepted 22 April 2009

\begin{abstract}
This study incorporated expert knowledge into the classical quadratic programming approach, i.e., Modern Portfolio Theory (MPT), through fuzzy set theory; in obtaining portfolio return optimization involving direct real estate investment. Two fuzzy mathematical programming models were uniquely specified and estimated in this study, namely, Zimmermann's (2001) fuzzy tactical asset allocation (FTAA) flexible programming model and Ramik and Rimanek's (1985) FTAA robust programming model. These approaches try to overcome the drawbacks of traditional asset allocation models by including expert adjustment in the presence of imprecise information. The findings suggest that the fuzzy tactical asset allocation (FTAA Flexible Model), with the inclusion of expert judgments which contain information usually not found in historical data, is able to produce a portfolio just as efficient as traditional asset allocation models while minimizing the potential issues due to imprecision and vagueness of information. Meanwhile, the FTAA Robust Model proffers a more evenly-distributed, yet with higher risks and lower returns, portfolio. Aside from the lack of emphasis on portfolio risks minimization, one reason attributed to such anomaly is the low level of returns of high-risk stocks that are not selected by MPT and FTAA Flexible Models. It results in a unique situation where portfolio diversification does not necessarily guarantee an efficient investment decision.
\end{abstract}

KEYWORDS: Modern portfolio theory; Imprecise information; Fuzzy linear programming; Portfolio selection, Decision making

\section{INTRODUCTION}

In an intricate and dynamic market, decision making is a complex human cognitive process with regard to uncertainties such as price and interest volatility. Therefore, institutional investors and practitioners are always immersed in managing their investment portfolios, not only to optimize returns, but more importantly to minimize potential risks. Risk diversification has been a main theme in many previous studies on portfolio management, first seen in the mean-variance modern portfolio theory (MPT) by Markowitz in 1952. However, since the reliability of MPT, as well 
as other mathematical models in deciding the optimal investment allocation for a real estateonly portfolio (Olaleye, 2008) or a mixed-asset portfolio (Falkenbach, 2009), depends mostly on availability of relevant market data, sometimes they might not be able to accurately reflect real world situations. Thus, these market data do not represent one's decision making as some information are not quantifiable in nature, i.e. the human cognitive process. Expert judgment seems to offer an acceptable alternative to tackle this problem ( $\mathrm{Su}, 2007)$.

By relaxing the crispness and precision for rigorous modeling and enabling a robust summary of expert knowledge, fuzzy logic systems can assist decision makers in their portfolio selection. The foundation of fuzzy logic for expressing imprecise, vague and uncertain information was first proposed by Zadeh (1964). His model/method has since been developed and widely used in investment, operating design and decision-making, along with information technology, artificial intelligence, management science and urban planning. Ko and Cheng (2003) emphasized that fuzzy logic not only can provide an approximate but also effective descriptions for highly complex, ill-defined, or difficult-to-analyze mathematical systems. The fuzzy approach can capture uncertainty in a realistic state as well.

Yet, the application of fuzzy set theory in real estate investment, especially one's allocation of such in investment portfolios, has been a relatively unexplored area. How does real estate investment, known for its capabilities of hedging against uncertainties such as inflation, influence the dynamics of one's portfolio asset allocation? This paper attempts to fill this gap of knowledge by incorporating fuzzy set theory into the classical asset allocation models, i.e. MPT. In order to relax the crispness and precision in portfolio management, two fuzzy tactical asset allocation (FTAA) models, namely Zimmermann's (2001) FTAA flexible programming model and Ramik and Rimanek's (1985)
FTAA robust programming model, are applied in this study. These models incorporate fuzzy set theory and linear programming into the tactical asset allocation process.

Following the introduction, Section 2 reviews the relevant literature on real estate asset allocation. It is followed by a presentation of the methodology, approach and details of the model operation in Section 3. Section 4 provides details of the data set used for the modeling. Then, the results of our models are discussed and compared. Lastly, concluding remarks are provided.

\section{LITERATURE REVIEW}

This section reviews the previous asset allocation studies and relevant researches. Traditionally, asset allocation is based on the expected mean-variance (EMV) analysis. It relies on the premise that investors would diversify assets so as to optimize expected return while minimizing risk (volatility). An investor will trade-off between expected or anticipated return and risk, subject to various constraints since market imperfections cannot be ignored (Markowitz, 1952). This decision is not merely which securities to own, but how to allocate investors' wealth amongst securities. And asset allocation is a powerful tool for risk reduction (Kaplan, 1998). Yet, as the model relies greatly upon historical data as inputs to proffer recommendations on asset allocation and past performance of elements is an important influence on the decision (French, 2001), those inputs should be adjusted to reflect the understanding of the market (Kaplan, 1998). Without such adjustments, the credibility of the analytical result is compromised.

In order to overcome these problems, expert-knowledge is adopted in modeling. Expert judgments are pervasive and important to analytical systems (Fischhoff, 1989). It could be used in adjusting the expected return and variance in accordance with various fac- 
tors, which might not be taken into account by mathematical computations, for instance, the MPT. Keeney and von Winterfeldt (1989) noted that human linguistic qualifications are preferable to numerical expressions of knowledge because it can well express or reflect expert's vagueness. It is therefore necessary to integrate such qualification into model calculations. The use of fuzzy logic in expressing imprecise, ambiguous, vague and uncertain information into a scientific approach was introduced by Zadeh (1964) and later enhanced via the introduction of the concept of linguistic (non-numeric) variable in 1970, i.e. "high", "low" (Bellman and Zadeh, 1970).

The application of fuzzy set theory to decision-making and evaluation in different real estate issues has been well-documented, for instance in the geographical information system (GIS) for spatial analysis (Sui, 1992; Zeng and Zhou, 2001), as well as in housing sales performance predictions utilizing a computerbased decision support tool for investors and contractors (Perng et al., 2005). Furthermore, it has also been applied to property appraisal and the estimation of appropriate market value (Bagnoli and Smith, 1998; Pagourtzi et al., 2003). However, little research has been done on deploying fuzzy set theory in devising an optimum investment strategy, particularly when direct real estate investment is being considered as well as other financial products available on the market. In addition to stocks and bonds, real estate is a crucial element in an investment portfolio because, while lacking liquidity, it processes hedging effect against market uncertainties such as inflation and interest volatility, which could change the complexion of one's consideration in the asset allocation of investment portfolios. This study aims to explore the possibility in incorporating expert knowledge through fuzzy set theory to optimize investment portfolios involving direct real estate investment. Two fuzzy mathematical programming, namely "Flexible" and "Robust" models, are utilized in this study. These models concern the aspired level of objective function, the degree of constraints, and the vagueness of coefficients in linear programming.

\section{METHODOLOGY}

This study focuses on the portfolio selection problem and the incorporation of fuzzy set theory with expert-knowledge in traditional approaches for optimizing the diversification benefit under risk tolerance. In general, most investors who are risk-aversers prefer risk to be as low as possible in their investment strategy. One of the most appropriate and popular approaches, Modern portfolio theory (MPT), is utilized to constitute an optimized portfolio using the concept of asset allocation. It can find the portfolio which will minimize risk and maximize expected return.

\section{Modern Portfolio Theory (MPT)}

A portfolio under MPT can be modeled as a quadratic programming function, similar to linear programming. Suppose there are $n$ assets involved in the asset portfolio, the optimization for asset allocation in which the portfolio risk is minimized for a given level of expected return, can be expressed in an objective function and a few constraints as follows:

$$
\begin{aligned}
& \text { Minimize } \sigma_{p}^{2}=\sum_{i=1}^{n} \sum_{j=1}^{n} x_{i} x_{j} \sigma_{i j} \\
& \text { Subject to } \mu_{p}=\sum_{i=1}^{n} x_{i} \mu_{i} \\
& \mu_{p} \geq \mu_{o} \\
& \sum_{i=1}^{n} x_{i}=1 \\
& x_{i} \geq 0, \quad \forall i=1,2, \ldots, n
\end{aligned}
$$

where: $x_{i}$ is the proportion of portfolio allocated to asset $i ; \mu_{p}$ is the expected portfolio return; $\mu_{i}$ is the expected return on asset $i ; \mu_{o}$ is the given level of expected return; $\sigma_{i j}$ is the covariance between asset $i$ returns and asset $j$ returns. 
In Markowitz's MPT optimization, investors are predominantly risk-averse and obtain an optimized asset portfolio with the highest possible return at a given level of risk $\left(\sigma_{p}^{2}\right)$ subject to some constraints.

\section{Fuzzy Set Theory}

The desired level of return for an investor sometimes cannot be depicted by a precise numerical value. It is regarded as the linguistic vagueness. In order to address it, this study incorporates the fuzzy set theory into linear programming, usually perceived as a powerful tool in decision-making.

Fuzzy set theory can be viewed as the extension of a crisp set theory, which deals with the lexical uncertainty and provide assistance in making decisions. It can be expressed as follows.

$$
A=\left(x, \mu_{A}(x) \mid x \in U\right) \text { or } A=\sum_{i=1}^{n} \mu_{A}\left(x_{i}\right) / x_{i}
$$

where: $\mu_{A}(x)$ is a membership function (MF) of $x$ in set $A$ in the universe of discourse and its value maps to the space $[0,1]$, $\mu(x): X \rightarrow[0,1]$.

Note: The symbol $\sum$ implies union, but not addition.

The membership function represents the degree of belonging for $x$ in set $A$ in the interval $[0,1]$. The value of zero implies no membership and the value of one implies a complete membership. The MF can be formed as triangular, trapezoidal and bell-shape types.

\section{Definition of the fuzzy decision}

Linear programming in a fuzzy environment was first formulated by Bellman and Zadeh in 1970. The decision can be viewed as an intersection of objective functions and constricts, as well as the optimal solution for the objective.

Suppose that a fuzzy goal $\tilde{G}$ and a fuzzy constraint $\tilde{C}$ are given in alternative space. A fuzzy set decision $\tilde{D}$ is formed by the intersection of $\tilde{G}$ and $\tilde{C}$, which can be expressed as follows:

$$
\begin{aligned}
& \tilde{D}=\tilde{G} \cap \tilde{C} \\
& \text { with } \mu_{\tilde{D}}=\min \left\{\mu_{\tilde{G}}, \mu_{\tilde{C}}\right\}
\end{aligned}
$$

In general, when goals $\tilde{G}_{1}, \ldots, \tilde{G}_{n}$ and $m$ constraints $\tilde{C}_{1}, \ldots, \tilde{C}_{m}$ are given, the resultant decision can be expressed as follows:

$$
\begin{aligned}
& \tilde{D}=\tilde{G}_{1} \cap \tilde{G}_{2} \cap \ldots \cap \tilde{G}_{n} \cap \tilde{C}_{1} \cap \tilde{C}_{2} \cap \ldots \cap \tilde{C}_{m} \\
& \mu_{\tilde{D}}=\min \left\{\mu_{\tilde{G}_{1}}, \mu_{\tilde{G}_{2}}, \ldots, \mu_{\tilde{G}_{n}}, \mu_{\tilde{C}_{1}}, \mu_{\tilde{C}_{2}}, \ldots, \mu_{\tilde{C}_{m}}\right\} \\
& n, m \in N \\
& \mu_{\tilde{D}}=\min \left\{\mu_{i}\right\}
\end{aligned}
$$

The model definition is represented in Figure 1.

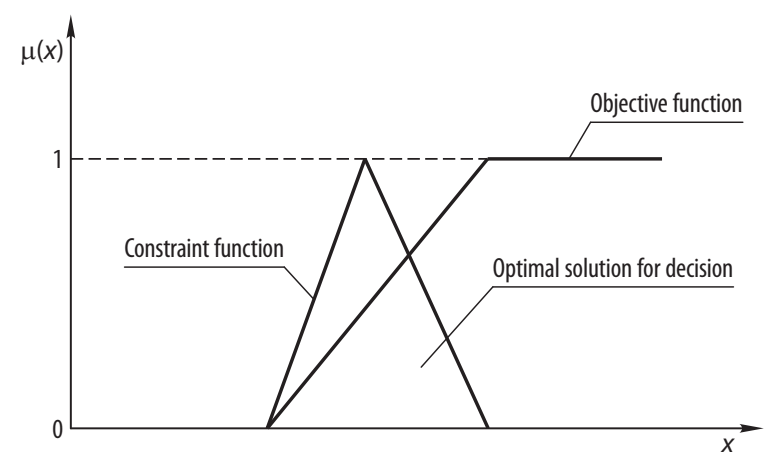

Figure 1. Decision-making in fuzzy environment

However, optimal fuzzy solution is not easy to interpret. Because of that, the result has to be defuzzified by converting the outcome into corresponding non-fuzzy value. It is appropriate to recommend that the crisp $D_{m}$ is a subset of $D$ with the highest degree of membership function, as the optimal decision.

$$
\begin{aligned}
& \mu_{D x}(x)=\operatorname{Max} \mu_{\tilde{D}}(x) \\
& \mu_{D x}(x)=\operatorname{Max} \operatorname{Min}\left\{\mu_{i}(x)\right\}
\end{aligned}
$$




\section{Zimmermann's (2001) FTAA flexible programming model}

Before focusing on Zimmermann's FTAA flexible programming model, classical linear programming is introduced. Mathematically speaking, it can be stated as:

$$
\begin{aligned}
& \text { Max } f(x)=c^{T} x \\
& \text { Such that } A x \leq b \\
& x \geq 0 \\
& \text { with } A \in R^{m \times n}, b \in R^{m}, c \in R^{n}
\end{aligned}
$$

All coefficient of $A, b$, and $c$ are crisp numbers and all constraints must be strictly satisfied. $x^{*}$ is called a solution of PL problem if $c x^{*} \geq c x$ for all $x \in X$. It is always considered a special kind of decision model in which its decision spare is satisfied all "goals" and "constricts".

However, as stated before, an investor's desired level of return sometimes cannot be represented by a precise numerical value. To address this issue, the fuzzy set theory is incorporated in a classical linear programming structure (6). Assume that an investor can establish an aspiration level $z$, that the objective function is achieved and each constrict is modeled as a fuzzy set. It can be expressed as follows:

Find $x$

Such that $c^{T} x \geqq z$

$$
\begin{aligned}
& A x \leqq b \\
& x \geqq 0 \\
& A \in R^{m \times n}, b \in R^{m}, x \in R^{n}
\end{aligned}
$$

where: $c$ objective function; $A$ constraint function; $z$ aspiration level; $m$ number of constraints; $n$ number of goals; $R^{m \times n}: m \times x$ real matrix.

$\lesssim$ and $\geqq$ denote the fuzzified version of $\leq$ and $\geq$ and have the linguistic interpretations of "essentially smaller than or equal to" and "essentially greater than equal to".
Since the $n$-vector $x$ is variable symmetric to both the objective and constraint functions, their coefficients can be substituted by $\left(\begin{array}{l}-C \\ A\end{array}\right)=B$ and $\left(\begin{array}{l}-z \\ b\end{array}\right)=d$.

The model (7) becomes:

Find $x$

Such that $B x \leqq d$

$x \geq 0$

$B \in R^{(m+1) \times n}, x \in R^{n}, d \in R^{(m+1)}$

$\mu_{i}(x)(\mathrm{MF})$ for $i=1, \ldots, m+1$ are assumed to be linear, increasing monotonically from 0 to 1 over the tolerance interval $\left[d_{i}, d_{i}+p_{i}\right]$ as:

$$
\mu_{i}(x)=\left\{\begin{array}{l}
1 \\
1-\frac{(B x)_{i}-d_{i}}{p_{i}} \\
0
\end{array}\right.
$$

$$
\begin{aligned}
& \text { if }(B x)_{i} \leq d_{i} \\
& \text { if } d_{i} \leq(B x)_{i} \leq d_{i}+p_{i} \\
& \text { if }(B x)_{i} \geq d_{i}+p_{i} \\
& \text { for } i=1, \ldots, m+1
\end{aligned}
$$

$p_{i}$ are constants subjectively chosen to represent the admissible violation of constraint and objective. According to Bellman and Zadeh (1970):

$$
D(x)=\min _{i=1}^{m+1}\left\{1-\frac{(B x)_{i}-d_{i}}{p_{i}}\right\}
$$

The crisp optimal solution is defined along the formulation

$$
D^{m}\left(x_{0}\right)=\max _{x \geq 0} \min _{i=1}^{m+1}\left\{1-\frac{(B x)_{i}-d_{i}}{p_{i}}\right\}
$$

Introducing a new variable $\lambda$ in the fuzzy set discussion, it can be illustrated simply as Figure 2. 


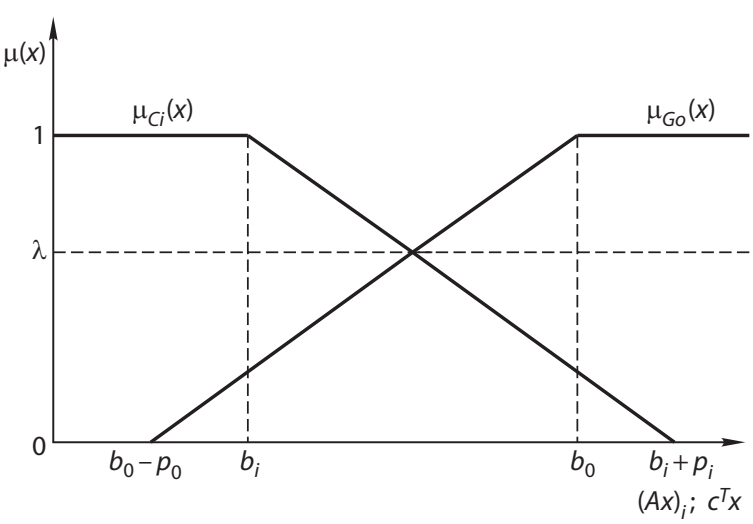

Figure 2. The solution $\lambda$ in fuzzy environment

$\operatorname{Max} \lambda$

Such that $\lambda p_{i}+(B x)_{i} \leq d_{i}+p_{i}, i=1, \ldots, m+1$

$$
\begin{aligned}
& 0 \leq \lambda \leq 1 \\
& x \geq 0
\end{aligned}
$$

For all feasible solutions, $\lambda^{*}$ can be interpreted as the degree of achievability of optimal solution of this fuzzy linear programming.

\section{Ramik and Rimanek's (1985) FTAA robust programming model}

However, coefficients of functions are sometimes ambiguous in nature. It should be modeled with fuzzy set theory, namely "Robust Programming".

For Ramik and Rimanek's approach, the optimization problem is defined as:

Maximizing (minimizing) the real function of $n$ real variables,

$$
\begin{aligned}
& f\left(x_{1}, x_{2}, \ldots, x_{n}\right) \\
& \text { Subject to } \\
& \tilde{a}_{i 1} x_{1} \oplus \tilde{a}_{i 2} x_{2} \oplus \ldots \oplus \tilde{a}_{i n} x_{n} \leq \tilde{b}_{i} \\
& i=1, \ldots, m \\
& x_{j} \geq 0, j=1, \ldots, n
\end{aligned}
$$

where: $\tilde{a}_{i j} \& \tilde{b}_{i j} \in M_{L i-R i}, L-R$ fuzzy numbers (Trapezoid fuzzy numbers); $\oplus$ denotes the extended addition.

For $L-R$ fuzzy numbers, $\tilde{a}_{i j}=\left(m_{i j}, n_{i j}, \alpha_{i j}, \beta_{i j}\right)$ and $\tilde{b}_{i j}=\left(p_{i j}, q_{i j}, \gamma_{i j}, \delta_{i j}\right)$

They assert that $\tilde{a} \leq \tilde{b}$ is valid if,

$$
\begin{aligned}
& \varepsilon_{L}(\gamma-\alpha) \leq p-m \\
& \varepsilon_{R}(\beta-\delta) \leq q-n \\
& \delta_{L}(\gamma-\alpha) \leq p-m \\
& \delta_{R}(\beta-\delta) \leq q-n
\end{aligned}
$$

where the above fuzzy numbers are defined as:

$$
\begin{aligned}
& \varepsilon_{R}=\sup \{\mu ; R(\mu)=R(0)=1\} \\
& \delta_{R}=\inf \left\{\mu: R(\mu)=\lim _{s \rightarrow+\infty} R(s)\right\}
\end{aligned}
$$

Rewriting the fuzzy linear programming (13) with the above inequalities, the extended operation of the product of the fuzzy numbers and variable $x$ of the constraint function is given as:

$$
\begin{aligned}
& \tilde{a}_{i 1} x_{1} \oplus \tilde{a}_{i 2} x_{2} \oplus \cdots \oplus \tilde{a}_{i n} x_{n}= \\
& =\left(\sum_{j=1}^{n} m_{i j} x_{j} \cdot \sum_{j=1}^{n} n_{i j} x_{j} \bullet \sum_{j=1}^{n} \alpha_{i j} x_{j} \bullet \sum_{j=1}^{n} \beta_{i j} x_{j}\right)
\end{aligned}
$$

The constraint function (14) can be written as follows:

$$
\begin{aligned}
-\varepsilon_{L i}\left(\sum_{j=1}^{n} \alpha_{i j} x_{j}-\gamma_{i}\right) & \leq p_{i}-\sum_{j=1}^{n} m_{i j} x_{j} \\
-\delta_{L i}\left(\sum_{j=1}^{n} \alpha_{i j} x_{j}-\gamma_{i}\right) & \leq p_{i}-\sum_{j=1}^{n} m_{i j} x_{j} \\
\varepsilon_{R i}\left(\sum_{j=1}^{n} \beta_{i j} x_{j}-\delta_{i}\right) & \leq q_{i}-\sum_{j=1}^{n} n_{i j} x_{j} \\
\delta_{R i}\left(\sum_{j=1}^{n} \beta_{i j} x_{j}-\delta_{i}\right) & \leq q_{i}-\sum_{j=1}^{n} n_{i j} x_{j}
\end{aligned}
$$

Before the implementation of these programming models, it is important to identify the parameters. For Zimmermann's FTAA flexible programming model, the admissible violation of portfolio risk, return and proportion of assets are hypostatized to be $2 \%, 0.4 \%$ and $20 \%$ respectively. For Ramik and Rimanek's FTAA robust programming model, $\tilde{a}$ and $\tilde{b}$ 
should be non-negative. In order to simplify the computation, $\alpha$ and $\beta$ are presumed to be at $0.2 \%$. $\gamma$ and $\delta$ are presumed to be at $0.3 \%$. These fuzzy programming models can be solved with solvers in Excel or other optimal tools (i.e. MATLAB). In our study, the solver of Excel is utilized to optimize the asset portfolio.

\section{THE DATA SETS FOR ASSET ALLOCATION MODELS}

For the localized portfolio in Hong Kong, the Hang Seng Composite Industry Index (HSCII), HSBC Hong Kong Dollar Bond Index and Private Domestic Price Index, from July 2000 to May 2008, are deployed for our study. The corresponding sectors are shown in Tables 1 and 2.

Table 1. The corresponding sectors of HSCII

\begin{tabular}{ll}
\hline \multicolumn{2}{l}{ Hang Seng Composite Industry Index (HSCII) } \\
\hline Energy & Utilities \\
Material & Financials \\
Industrial goods & $\begin{array}{l}\text { Properties \& } \\
\text { Construction } \\
\text { (Prop. \& Const.) }\end{array}$ \\
& Information \\
Consumer goods & Technology (I.T.) \\
& Conglomerates \\
Services & \\
\hline
\end{tabular}

Source: Hang Seng Indexes Company Limited

Table 2. The corresponding classes of the Private Domestic Price Index

\begin{tabular}{l}
\hline Private Domestic Price Index \\
\hline Class A - saleable area less than $40 \mathrm{~m}^{2}$ \\
Class B - saleable area of $40 \mathrm{~m}^{2}$ to $69.9 \mathrm{~m}^{2}$ \\
Class C - saleable area of $70 \mathrm{~m}^{2}$ to $99.9 \mathrm{~m}^{2}$ \\
Class D - saleable area of $100 \mathrm{~m}^{2}$ to $159.9 \mathrm{~m}^{2}$ \\
Class E - saleable area of $160 \mathrm{~m}^{2}$ or above \\
\hline
\end{tabular}

Source: Rating and Valuation Department (RVD); HKSAR
The Hang Seng Composite Industry Index (HSCII) consists of the top 200 stocks from 11 industries in terms of average market capitalization in the past 12 months, including 38 properties \& construction companies. It serves as a good indicator for the performance of various sectors of the Hong Kong stock market. In this study, the sector of properties \& construction is perceived as indirect property investments.

The Private Domestic Price Index is computed by the Rating and Valuation Department in measuring the price adjustments of private properties with its quality being kept constant. In this study, this figure is used as a proxy for the performance of direct property investments.

Moreover, the HSBC Hong Kong Dollar Bond Index represents Hong Kong Dollar Bonds and measures the performance of Hong Kong Dollar denominated fixed rate debt instruments issued by the Hong Kong SAR Government and other non-government entities.

The return of an investment is the aggregate of the dividend yield and the value appreciation in the period of assessment.

$$
\Delta T R_{t}=\frac{I_{t}-I_{t-1}}{I_{t-1}}+D_{t}
$$

where: $\Delta T R_{t}$ is the total return of period $t ; I_{t}$ is the index value at the end of period $t ; I_{t-1}$ is the index value at the end of period $t-1 ; D_{t}$ is the dividend yield during the period $t$.

Note: Dividend yield was missing in some observation periods in some sectors, which was assigned the corresponding average of dividend yield of remaining periods. 


\section{ANALYSIS}

The efficient frontier of portfolio with MPT is established. The monthly expected returns and standard deviations of individual assets involved in portfolio are presented and summarized in Table $3{ }^{1}$.

The resulting Markowitz MPT optimization frontier is illustrated in Figure 3. It consists of portfolios with the combination of assets that maximize the expected portfolio return for a given level of risk. Portfolios on the frontier are regarded as optimum portfolios. To do this, the Hong Kong dollar bonds are considered a riskfree asset in our study. The selected portfolio consists of $19.43 \%$ in Energy, $43.98 \%$ in Utilities, $13.50 \%$ in Class D, $20.13 \%$ in Class E, and $2.97 \%$ in Hong Kong dollar bonds. The monthly expected return and standard deviation are $1.6 \%$ and $2.89 \%$ respectively (Point MP).

Table 3. The monthly expected return and standard deviation of allocated assets

\begin{tabular}{lllllll}
\hline & Energy & Material & Industrial goods & Consumer goods & Services & Telecom \\
\hline $\begin{array}{l}\text { Expected } \\
\text { return }\end{array}$ & $2.80 \%$ & $2.89 \%$ & $0.00 \%$ & $1.59 \%$ & $1.22 \%$ & $0.91 \%$ \\
Std. Dev. & $8.45 \%$ & $11.30 \%$ & $8.31 \%$ & $6.80 \%$ & $6.03 \%$ & $10.31 \%$ \\
\hline & Utilities & Financials & Prop. \& Const. & I.T. & Conglomerates & \\
\hline $\begin{array}{l}\text { Expected } \\
\text { return }\end{array}$ & $1.49 \%$ & $1.38 \%$ & $1.41 \%$ & $0.55 \%$ & $0.73 \%$ & \\
Std. Dev. & $3.34 \%$ & $5.64 \%$ & $7.99 \%$ & $10.01 \%$ & $6.82 \%$ & Class E \\
\hline & Class A & Class B & Class C & Class D & Bond Index \\
\hline $\begin{array}{l}\text { Expected } \\
\text { return }\end{array}$ & $0.87 \%$ & $0.76 \%$ & $0.95 \%$ & $1.05 \%$ & $1.18 \%$ & $0.68 \%$ \\
Std. Dev. & $2.38 \%$ & $2.43 \%$ & $2.81 \%$ & $2.70 \%$ & $3.50 \%$ & $1.49 \%$ \\
\hline
\end{tabular}

Sources: Hang Seng Indexes Company Limited; Rating and Valuation Department (RVD), HKSAR; Bloomberg

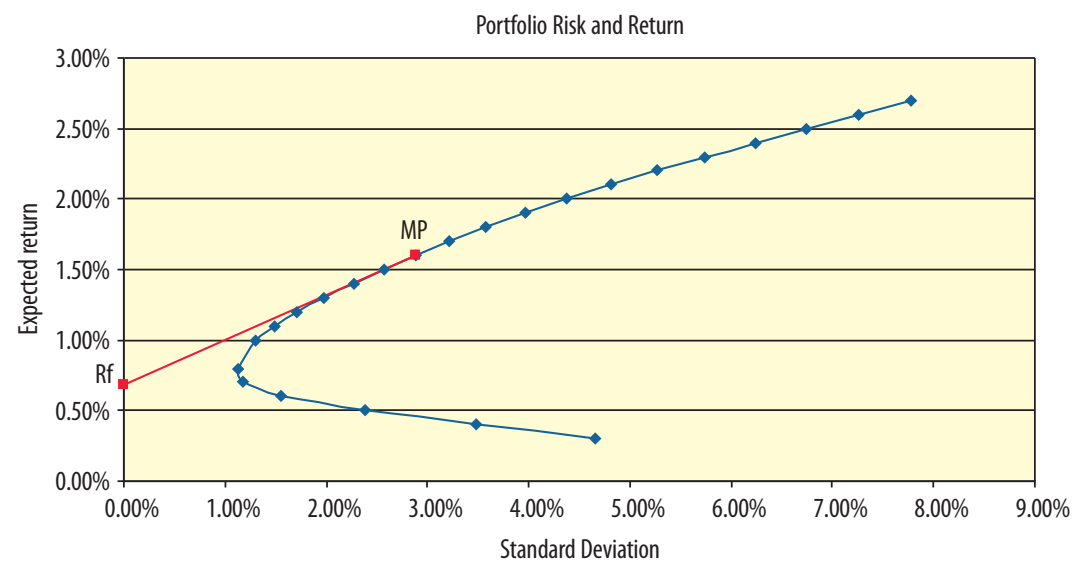

Figure 3. The efficient frontier of the Markowitz MPT optimization model

\footnotetext{
${ }^{1}$ For the correlation coefficients and covariances, as required in the computations of the programming models, refer to Appendices 1 and 2.
} 
The expected return and portfolio standard deviation from MPT are considered the same as that in the fuzzy linear programming models, which investors wish to achieve. The corresponding model estimations of programming are presented in Tables 4 and 5, and the resultant asset allocations of the three models are illustrated in Table 6.
Some differences can be observed in the allocation of assets under the three programming models (Table 6). On the one hand, the asset allocations in the MPT and FTAA flexible programming model are similar. They have a high allocation of $44 \%$ of capital to Utilities stocks, about one-third to direct property investment (Class D and Class E), and close

Table 4. Zimmermann's FTAA flexible programming model coefficients

\begin{tabular}{llllllll}
\hline Riskp $+\lambda p_{1}$ & $7.0939 \%$ & $\leqq d_{1}+p_{1}$ & $7.0939 \%$ & $d_{1}$ & $5.0939 \%$ & $p_{1}$ & $2.0000 \%$ \\
Returnp $-\lambda p_{2}$ & $1.2000 \%$ & $\geqq d_{2}-p_{2}$ & $1.2000 \%$ & $d_{2}$ & $1.6000 \%$ & $p_{2}$ & $0.4000 \%$ \\
Whole proportion $+\lambda p_{3}$ & $120.0000 \%$ & $\leqq d_{3}+p_{3}$ & $120.0000 \%$ & $d_{3}$ & $100.00 \%$ & $p_{3}$ & $20.0000 \%$ \\
\hline
\end{tabular}

Table 5. Ramik and Rimanek FTAA robust programming model coefficients

\begin{tabular}{llllllllll}
\hline$m$ & $1.3501 \%$ & $p$ & $1.4500 \%$ & $\varepsilon_{L}$ & $100.0000 \%$ & $-\varepsilon_{L}(\alpha-\gamma)$ & $0.1000 \%$ & $\leqq p-m$ & $0.0999 \%$ \\
$n$ & $1.5501 \%$ & $q$ & $1.7500 \%$ & $\delta_{L}$ & $0.0000 \%$ & $-\delta_{L}(\alpha-\gamma)$ & $0.0000 \%$ & $\leqq p-m$ & $0.0999 \%$ \\
$\alpha$ & $0.2000 \%$ & $\gamma$ & $0.3000 \%$ & $\varepsilon_{R}$ & $100.0000 \%$ & $\varepsilon_{R}(\beta-\delta)$ & $-0.1000 \%$ & $\leqq q-n$ & $0.1999 \%$ \\
$\beta$ & $0.2000 \%$ & $\delta$ & $0.3000 \%$ & $\delta_{R}$ & $0.0000 \%$ & $\delta_{R}(\beta-\delta)$ & $0.0000 \%$ & $\leqq q-n$ & $0.1999 \%$ \\
\hline
\end{tabular}

Table 6. Comparisons of different asset allocation models

\begin{tabular}{llll}
\hline & MPT & $\begin{array}{l}\text { FTAA Flexible } \\
\text { Programming Model }\end{array}$ & $\begin{array}{l}\text { FTAA Robust } \\
\text { Programming Model }\end{array}$ \\
\hline Energy & $19.4251 \%$ & $19.3890 \%$ & $18.5593 \%$ \\
Material & $0.0000 \%$ & $0.0000 \%$ & $6.0215 \%$ \\
Industrial goods & $0.0000 \%$ & $0.0000 \%$ & $4.5160 \%$ \\
Consumer goods & $0.0000 \%$ & $0.0000 \%$ & $5.3414 \%$ \\
Services & $0.0000 \%$ & $0.0000 \%$ & $5.1486 \%$ \\
Telecom. & $0.0000 \%$ & $0.0000 \%$ & $4.9858 \%$ \\
Utilities & $43.9824 \%$ & $44.1091 \%$ & $5.2910 \%$ \\
Financials & $0.0000 \%$ & $0.0000 \%$ & $5.2349 \%$ \\
Prop. \& Const. & $0.0000 \%$ & $0.0000 \%$ & $5.2500 \%$ \\
IT & $0.0000 \%$ & $0.0000 \%$ & $4.8031 \%$ \\
Conglomerates & $0.0000 \%$ & $0.0000 \%$ & $4.8956 \%$ \\
Class A & $0.0000 \%$ & $0.0000 \%$ & $4.9858 \%$ \\
Class B & $0.0000 \%$ & $0.0000 \%$ & $4.9126 \%$ \\
Class C & $0.0000 \%$ & $0.0000 \%$ & $5.0112 \%$ \\
Class D & $13.4982 \%$ & $13.1435 \%$ & $5.0616 \%$ \\
Class E & $20.1287 \%$ & $20.3370 \%$ & $5.1316 \%$ \\
Bond Index & $2.9656 \%$ & $3.0213 \%$ & $4.8701 \%$ \\
\hline Total & $100 \%$ & $100 \%$ & $100 \%$ \\
\hline
\end{tabular}


to one-fifth to Energy stocks. In short, both MPT and FTAA Flexible Programming Model emphasize on low-risk and low-return investments. On the other hand, the FTAA robust programming model produces a much different allocation pattern, as compared to the other two. Aside from the allocation of $18.5 \%$ of resources to Energy stocks, which is similar to that under MPT and FTAA Flexible Programming Model, the remaining capital is very evenly distributed to every other stock and real estate investment options, ranging from $4.5 \%-6 \%$. One reason behind such disparities is that the portfolio risk in this model is necessarily not restricted, which allows room for relatively riskier investment. Thus, the resultant asset allocation differs from that of both MPT and FTAA flexible programming model.

The respective performance indicators of portfolios generated by the two fuzzy models are presented in Table 7 below.

Table 7.Zimmermann's FTAA flexible and Ramik and Rimanek FTAA robust programming model results

\begin{tabular}{lll}
\hline & $\begin{array}{l}\text { FTAA Flexible } \\
\text { Programming } \\
\text { Model }\end{array}$ & $\begin{array}{l}\text { FTAA Robust } \\
\text { Programming } \\
\text { Model }\end{array}$ \\
\hline $\begin{array}{l}\text { Portfolio } \\
\text { Risk }\end{array}$ & $0.0835 \%$ & $0.2063 \%$ \\
$\begin{array}{l}\text { Portfolio } \\
\text { Std. Dev. }\end{array}$ & $2.8894 \%$ & $4.5423 \%$ \\
$\begin{array}{l}\text { Portfolio } \\
\text { Return }\end{array}$ & $1.6000 \%$ & $1.4501 \%$ \\
$\begin{array}{l}\text { Expected } \\
\text { Return }\end{array}$ & $1.6000 \%$ & $1.6000 \%$ \\
\hline
\end{tabular}

As shown in Table 7, both the portfolio return and standard deviation of the FTAA flexible programming model are pretty much identical as that in the MPT portfolio. Meanwhile, the result obtained from the FTAA robust programming model suggests a portfolio with slightly lower returns and slightly higher risks than the other two portfolios. It implies that fuzzy programming portfolios, under certain rules, are able to perform just as well as the traditional method in terms of minimizing risks. However, the portfolio derived from Ramik and Rimanek's FTAA robust programming model presents a unique situation in which lower returns are obtained from riskier investments. This anomaly can be explained by the performance of stock options other than the ones chosen by the MPT/FTAA flexible programming model (Table 3). Albeit with higher expected monthly returns for some investment options over Utilities and Energy stocks, the disparities are not enough to compensate the risks involved. The risks for some stock options are considered too high that they are even less preferable to direct real estate investments from the perspective of an average risk-averse investor. This leads to a scenario in which risky investment does not necessarily bring higher rewards and diversification of assets does not necessarily minimize risks.

In the previous analysis, the objective and constraints (aspiration level, portfolio risk and expected return) are envisaged to be fuzzy in programming models. It is observed that fuzzy programming models can perform well in minimizing portfolio risk given the aspired level of return. It can provide an intuitive way to capture the ambiguous and vague information in an intricate and dynamic market. The efficiency of asset allocation can be improved with the inclusion of expert-knowledge. In the real world, the expert/investors would prefer a possible range of information rather than a precise function value. Compared to MPT, a main advantage of the FTAA models is that institutional investors and practitioners can describe their aspired level in terms of fuzzy instead of a precise formulation and handle tolerance violation easily while the same expected return can be achieved. In a fuzzy environment, these models will select a set of feasible alternatives, which satisfy the objective(s) and constraints. 


\section{CONCLUDING REMARKS}

This paper incorporates the fuzzy concept in linear programming to obtain the best possible outcome in portfolios, when direct real estate investment is included. Despite not as liquid as other investment options on the market, real estate helps hedge uncertainties, such as inflation and interest rate volatilities, which change the complexion of one's investment behaviour. The findings suggest that the fuzzy tactical asset allocation (FTAA flexible programming model), with the inclusion of expert judgments which contain information usually not found in historical data, is able to produce a portfolio just as efficient as traditional asset allocation models while minimizing the possible issues induced by imprecision and vagueness of information. Meanwhile, the FTAA robust programming model proffers a more evenly-distributed portfolio, yet surprisingly with higher risks and lower returns. Aside from the lack of emphasis on portfolio risks minimization, one reason attributed to such anomaly is the low level of returns among high-risk stocks not selected by MPT and FTAA flexible programming models. It results in a unique situation where portfolio diversification does not necessarily guarantee an efficient investment decision. In addition, investors should pay attention to the potential drawbacks for implementing FTAA models when too many constraints are incorporated. It could complicate the optimization process and thus renders these models difficult to use for laymen. Hence, further studies should focus on the development of the determination approach of membership functions.

\section{ACKNOWLEDGEMENT}

This study was funded by the Hong Kong Polytechnic University's Internal Grant. The authors would also like to thank Mr. Ka-hung YU for his assistance.

\section{REFERENCES}

Bagnoli, C. and Smith, H.C. (1998) The theory of fuzzy logic and its application to real estate valuation, Journal of Real Estate Research, 16(2), pp. 169-199.

Bellman, R.E. and Zadeh, L.A. (1970) Decisionmaking in a fuzzy environment, Management Science, 17(4), pp. B-141-B-164. DOI: 10.1287/ mnsc.17.4.B141

Falkenbach, H. (2009) Diversification benefits in the Finnish commercial property market, International Journal of Strategic Property Management, 13(1), pp. 23-35.

Fischhoff, B. (1989) Eliciting knowledge for analytical representation, IEEE Transactions on Systems, Man, and Cybernetics, 19(3), pp. 448-461.

French, N. (2001) Decision theory and real estate investment: An analysis of the decision-making processes of real estate investment fund managers, Managerial and Decision Economics, 22(7), pp. 399-410.

Kaplan, P. (1998) Asset allocation models using the Markowitz approach. Ibbotson Associates.

Keeney, R.L., and von Winterfeldt, D. (1989) On the uses of expert judgment on complex technical problems, IEEE Transactions on Engineering Management, 36(2), pp. 83-86.

Ko, C.H. and Cheng, M.Y. (2003) Hybrid use of AI techniques in developing construction management tools, Automation in Construction, 12(3), pp. 271-281.

Markowitz, H.M. (1952) Portfolio selection, Journal of Finance, 7(1), pp. 77-91.

Olaleye, A. (2008) Property market nature and the choice of property portfolio diversification strategies: The Nigeria experience, International Journal of Strategic Property Management, 12(1), pp. 35-51.

Pagourtzi, E., Assimakopoulos, V., Hatzichristos, T. and French, N. (2003) Real estate appraisal: A review of valuation methods, Journal of Property Investment and Finance, 21(4), pp. 383401.

Perng, Y. H., Hsueh, S.L. and Yan, M.R. (2005) Evaluation of housing construction strategies in China using fuzzy-logic system, International Journal of Strategic Property Management, 9(4), pp. 215-232. 
Ramik, J. and Rimanek, J. (1985) Inequality relation between fuzzy numbers and its use in fuzzy optimization, Fuzzy Sets and Systems, 16(2), pp. 123-138.

Sui, D.Z. (1992) A fuzzy GIS modeling approach for Urban land evaluation, Computers Environment and Urban Systems, 16(2), pp. 101-115.

$\mathrm{Su}, \mathrm{H} . Y$. (2007) International direct real estate asset allocation: A fuzzy decision-making approach. Master of Science thesis, Department of Real Estate, National University of Singapore.
Zadeh, L.A. (1964) Fuzzy Sets, ERL Report No. 6444, University of California at Berkeley, November 16, 1964.

Zimmermann, H.J. (2001) Fuzzy set theory - and its application $\left(4^{\text {th }} e d\right)$. Kluwer Academic Publishers, pp. 329-370.

Zeng, T.Q. and Zhou, Q. (2001) Optimal spatial decision making using GIS: A prototype of a real estate geographical information system (REGIS), International Journal of Geographical Information Science, 15(4), pp. 307-321.

\section{SANTRAUKA}

\section{SPRENDIMŲ PRIĖMIMO METODAS ESANT NEAPIBRĖŽTUMUI TIESIOGINIŲ NEKILNOJAMOJO TURTO INVESTICIJŲ PORTFELIO VALDYMO METU}

\section{Eddie Chi Man HUI, Otto Muk Fai LAU, Kak Keung LO}

Šis tyrimas įtraukia ekspertines žinias ị klasikinę kvadratinio programavimo metodika, pavyzdžiui, moderniaja portfelio valdymo teorija, per neapibrèžtuju aibių teorija, siekiant optimizuoti portfelio grąža, apimant tiesiogines nekilnojamojo turto investicijas. Šiame tyrime išsamiai aprašomi ir įvertinami du neapibrèžtojo matematinio programavimo modeliai. Tai Zimmermann (2001) neapibrèžtasis aktyvų paskirstymo lankstusis programavimo modelis ir Ramik bei Rimanek (1985) neapibrěžtasis aktyvu paskirstymo robustinis programavimo modelis. Juos taikant bandoma pašalinti tradicinių aktyvu paskirstymo metodu trūkumus i̇traukiant ekspertų siūlomus pakeitimus nesant tikslios informacijos. Nustatyta, kad neapibrèžtasis aktyvų paskirstymas (neapibrež̌tasis aktyvų paskirstymo lankstusis programavimo modelis) kartu su ekspertų vertinimais, paprastai apimančiais informacija, kurios negalima rasti tarp istoriniu duomenu, leidžia sudaryti toki pati efektyvu portfelį, kaip ir tradiciniai aktyvu paskirstymo modeliai, tačiau minimizuojant potencialius nesutarimus, kurių atsiranda dèl netikslios ir neapibrèžtos informacijos. Neapibréžtasis aktyvų paskirstymo robustinis programavimo modelis siūlo tolygiau paskirstyta, tačiau rizikingesnị ir ne toki pelningą portfelị. Be portfelio rizikos minimizavimo trūkumo, dar viena priežastis, priskiriama prie šios anomalijos, yra maža didelès rizikos akcijų graža, kuri nẻra pasirenkama moderniojoje portfelio valdymo teorijoje ir neapibrèžtujų aktyvų paskirstymo lanksčiuosiuose programavimo modeliuose. Kaip rezultatas gaunama unikali situacija, kai portfelio diversifikavimas nebūtinai garantuoja efektyvų investavimo sprendimą. 


\begin{tabular}{|c|c|c|c|c|c|c|c|c|c|c|c|c|c|c|c|c|c|c|}
\hline & $\begin{array}{l}\text { хәрич } \\
\text { puog }\end{array}$ & $\begin{array}{l}8 \\
0 \\
0\end{array}$ & 光. & $\stackrel{0}{\stackrel{0}{0}}$ & $\begin{array}{l}8 \\
\dot{0} \\
\dot{0}\end{array}$ & $\begin{array}{l}\infty \\
0 \\
0 \\
i\end{array}$ & $\begin{array}{l}\tilde{O}_{0} \\
\stackrel{0}{0} \\
\stackrel{1}{1}\end{array}$ & $\stackrel{0}{0}$ & $\begin{array}{l}\text { oे } \\
\stackrel{0}{0} \\
\text { i }\end{array}$ & $\begin{array}{l}8 \\
\stackrel{0}{0}\end{array}$ & 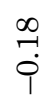 & $\begin{array}{l}0 \\
0 \\
0 \\
1\end{array}$ & $\begin{array}{l}\stackrel{0}{0} \\
\stackrel{0}{0}\end{array}$ & $\begin{array}{l}8 \\
\dot{0} \\
\dot{1}\end{array}$ & $\begin{array}{l}5 \\
0 \\
0\end{array}$ & $\begin{array}{l}\text { : } \\
\stackrel{0}{0}\end{array}$ & $\begin{array}{l}\infty \\
0 \\
0 \\
i\end{array}$ & 8 \\
\hline & 苗 sse ID & $\stackrel{4}{\stackrel{4}{0}}$ & $\begin{array}{l}0 \\
\stackrel{1}{0}\end{array}$ & $\begin{array}{l}\overrightarrow{0} \\
0\end{array}$ & $\begin{array}{l}\infty \\
0 \\
0\end{array}$ & $\stackrel{10}{\stackrel{1}{0}}$ & नै & $\stackrel{+}{\square}$ & $\stackrel{\infty}{-1}$ & $\stackrel{\infty}{+}$ & 웅. & $\stackrel{\infty}{-1}$ & $\stackrel{9}{+}$ & $\stackrel{H}{\sharp}$ & $\stackrel{+}{+!}$ & $\stackrel{\stackrel{2}{+}}{\circ}$ & $\underset{-}{8}$ & $\begin{array}{l}\infty \\
0 \\
0 \\
i\end{array}$ \\
\hline & đ sseto & $\stackrel{1}{\circ}$ & $\begin{array}{l}0 \\
-1 \\
0\end{array}$ & $\stackrel{8}{\circ}$ & $\stackrel{\infty}{-1}$ & ন̄ & 今. & $\stackrel{\circ}{\stackrel{0}{0}}$ & $\stackrel{0}{\circ}$ & $\begin{array}{l}0 \\
\stackrel{1}{0} \\
0\end{array}$ & $\stackrel{\infty}{0}$ & ֻิ & $\stackrel{\infty}{\stackrel{0}{0}}$ & $\stackrel{\infty}{0}$ & $\stackrel{N}{\mathfrak{N}}$ & \& & $\stackrel{10}{+1}$ & $\stackrel{8}{\circ}$ \\
\hline & ว sseโD & 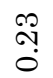 & ஸุ & ֻึ & $\stackrel{\leftrightarrow}{\circ}$ & $\stackrel{0}{\infty}$ & $\stackrel{\infty}{\rightarrow}$ & $\stackrel{10}{:}$ & 今. & ๙ึ. & 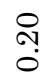 & $\ddot{n}$ & $\begin{array}{l}\infty \\
\infty \\
0 \\
0\end{array}$ & $\begin{array}{l}\infty \\
\infty \\
0 \\
0\end{array}$ & ن & $\stackrel{N}{\leftarrow}$ & $\stackrel{+}{+}$ & 今. \\
\hline & G sse[D & $\stackrel{\wp}{\infty}$ & $\begin{array}{l}\infty \\
\infty \\
0\end{array}$ & 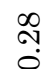 & 占 & $\stackrel{+}{+}$ & 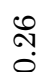 & ֻै & $\stackrel{+}{-!}$ & $\stackrel{\text { Hิ }}{+}$ & ลั & F্t: & $\begin{array}{l}\infty \\
\infty \\
\infty\end{array}$ & ن & $\begin{array}{l}\infty \\
\infty \\
\infty \\
0\end{array}$ & $\begin{array}{l}\infty \\
\stackrel{0}{0} \\
\stackrel{0}{0}\end{array}$ & $\stackrel{+}{t}$ & $\stackrel{0}{\circ}$ \\
\hline & V sseโD & $\stackrel{\circ}{\stackrel{0}{0}}$ & $\stackrel{\circ}{\circ}$ & 今. & $\stackrel{m}{\rightarrow}$ & : & $\stackrel{\circ}{?}$ & $\stackrel{H}{:}$ & ڤ. & $\stackrel{\substack{~ \\
0}}{0}$ & $\stackrel{\infty}{0}$ & $\stackrel{0}{:}$ & \& & $\begin{array}{l}\infty \\
\infty \\
0 \\
0\end{array}$ & $\begin{array}{l}\infty \\
\infty \\
0 \\
0\end{array}$ & $\stackrel{2}{2}$ & $\stackrel{\mathscr{P}}{+}$ & $\begin{array}{l}0 \\
\stackrel{-}{0}\end{array}$ \\
\hline & 'o[.8ิuo’ & $\stackrel{\text { g }}{\longrightarrow}$ & Lீ & 동 & 它 & $\begin{array}{l}\infty \\
\infty \\
\infty\end{array}$ & $\stackrel{+}{ \pm}$ & @. & $\stackrel{2}{2}$ & \& & $\stackrel{0}{1}$ & 8 & $\stackrel{0}{-1}$ & $\stackrel{F}{4}$ & $\vec{m}$ & คి & $\stackrel{\infty}{\sim}$ & 。 \\
\hline & LI & $\stackrel{\not}{\sharp !}$ & : & $\begin{array}{l}0 \\
0 \\
0\end{array}$ & :̊ & 둥 & $\stackrel{N}{\stackrel{N}{0}}$ & ஸै & छै. & $\begin{array}{l}0 \\
\ddot{0} \\
0\end{array}$ & \& & $\begin{array}{l}0 \\
\stackrel{0}{0} \\
0\end{array}$ & : & ลั & $\stackrel{0}{\sim}$ & : & $\begin{array}{l}0 \\
\stackrel{-1}{0}\end{array}$ & $\stackrel{\infty}{\stackrel{1}{0}}$ \\
\hline & $\begin{array}{r}{ }^{2} \text { 'suop } \\
\not 2 \cdot \text { dox }\end{array}$ & भै & ถึ่ & 8 & مْ & م્ & ț & 유 & $\stackrel{?}{\sim}$ & 8 & $\ddot{0}$ & \& & $\stackrel{\sim}{\sim}$ & Fै & ๙ึ้ & $\stackrel{\bullet}{\sim}$ & $\stackrel{\infty}{\sim}$ & 8 \\
\hline & 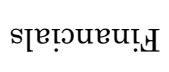 & $\stackrel{5}{\circ}$ & $\stackrel{10}{+}$ & $\stackrel{+}{+}$ & 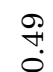 & $\stackrel{\mathscr{B}}{0}$ & : & $\stackrel{n}{\infty}$ & 8 & $\stackrel{n}{2}$ & $\ddot{0}$ & $\stackrel{m}{\mathfrak{r}}$ & ㅇ. & $\stackrel{H}{-}$ & 5 & $\stackrel{\circ}{\circ}$ & $\stackrel{\infty}{-1}$ & $\stackrel{\text { ô }}{0}$ \\
\hline & 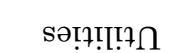 & ది & 움 & ลิ & gr & $\stackrel{H}{H}$ & 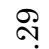 & 8 & s. & $\stackrel{\circ}{\not}$ & ๓้ & 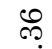 & $\stackrel{+}{\square}$ & $\stackrel{\bullet}{\sim}$ & $\stackrel{10}{=}$ & $\stackrel{\circ}{-}$ & 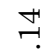 & ஜ \\
\hline & & 0 & 0 & 0 & 0 & 0 & 0 & -1 & 0 & 0 & 0 & 0 & D & D & 0 & 0 & D & $0^{\circ}$ \\
\hline & ·шоәә[ә $\mathrm{L}$ & ํํ & $\stackrel{\infty}{+}$ & 8 & مَ & $\begin{array}{l}\infty \\
0 \\
0\end{array}$ & 8 & คุ & 8 & ठํ. & $\stackrel{N}{N}$ & 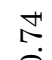 & $\stackrel{ }{=}$ & 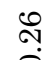 & $\stackrel{\infty}{=}$ & 옹. & 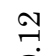 & oे \\
\hline & & & & & & & & & & & & & & & & & & \\
\hline D & 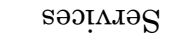 & 10 & 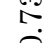 & . & 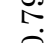 & o. & ๑. & $\stackrel{H}{4}$ & 0 & $\infty$ & $\Gamma$ & $\stackrel{\infty}{\infty}$ & s. & If & $\stackrel{\infty}{\infty}$ & $\stackrel{\sim}{N}$ & $\stackrel{0}{\sim}$ & $\stackrel{0}{\circ}$ \\
\hline$\pi$ & & & & & & & & & & & & & & & & & & \\
\hline త్ర & $\begin{array}{r}\text { spoo. } \\
\text { sәunsuo? }\end{array}$ & రै. & N & 6 & 8 & $\stackrel{2}{1}$ & مै & $\stackrel{g}{+}$ & $\stackrel{F}{+}$ & 10 & రి & 6 & $\stackrel{m}{=}$ & 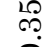 & ๑̣ & $\stackrel{m}{\longrightarrow}$ & $\stackrel{\infty}{\circ}$ & : \\
\hline 0 & spoo.8 & 0 & 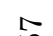 & 0 & 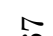 & 10 & 0 & 上 & 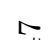 & & $\infty$ & -1 & 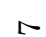 & $\infty$ & & $\sigma$ & - & $\circ$ \\
\hline శี & [ет.лұsnpu & $\stackrel{+}{0}$ & 0 & $\stackrel{0}{-}$ & $\stackrel{0}{0}$ & 0 & $\stackrel{0}{0}$ & on & $\stackrel{0}{0}$ & $\stackrel{0}{0}$ & 0 & 0 & $\stackrel{0}{0}$ & ơ & ơ & $\dot{0}$ & $\stackrel{0}{0}$ & i \\
\hline [n & 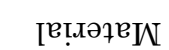 & 8 & 8 & 10. & N & $\stackrel{\mathscr{T}}{\mathscr{T}}$ & $\stackrel{\infty}{+}$ & 윔 & $\stackrel{10}{+}$ & กิ & $\mathscr{8}$ & ڤ? & ค & $\stackrel{\infty}{\infty}$ & จั & $\stackrel{\bullet}{-}$ & 움 & $\stackrel{\sim}{\sim}$ \\
\hline$\stackrel{0}{0}$ & & & & & & & & & & & & & & & & & & \\
\hline 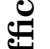 & К.8̊ләи' & 8 & తి. & $\stackrel{0}{?}$ & ญิ & $\begin{array}{l}\infty \\
\stackrel{\infty}{\infty}\end{array}$ & รี & ?ొ & 군 & F & $\stackrel{H}{\sharp}$ & F & $\stackrel{\sigma}{-}$ & คి & ๙ึ & 드. & $\stackrel{H}{\leftrightarrows}$ & $\stackrel{8}{0}$ \\
\hline 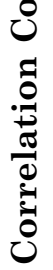 & & 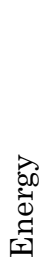 & 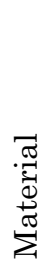 & 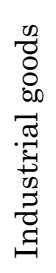 & $\begin{array}{l}\text { n } \\
\tilde{8} \\
0 \\
\infty \\
\tilde{0} \\
\tilde{0} \\
0 \\
0 \\
0 \\
0\end{array}$ & 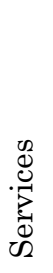 & $\begin{array}{l}\dot{\Xi} \\
\stackrel{0}{0} \\
\stackrel{\Xi}{0} \\
\stackrel{0}{0}\end{array}$ & : & 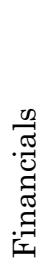 & 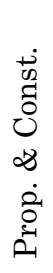 & 帠 & 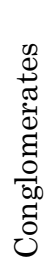 & $\begin{array}{l}\varangle \\
w \\
\text { w } \\
\text { ज़ } \\
\widetilde{U}\end{array}$ & 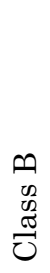 & $\begin{array}{l}0 \\
\text { Un } \\
\sigma \\
\sigma \\
0\end{array}$ & 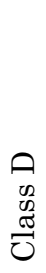 & 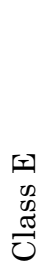 & 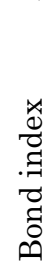 \\
\hline
\end{tabular}




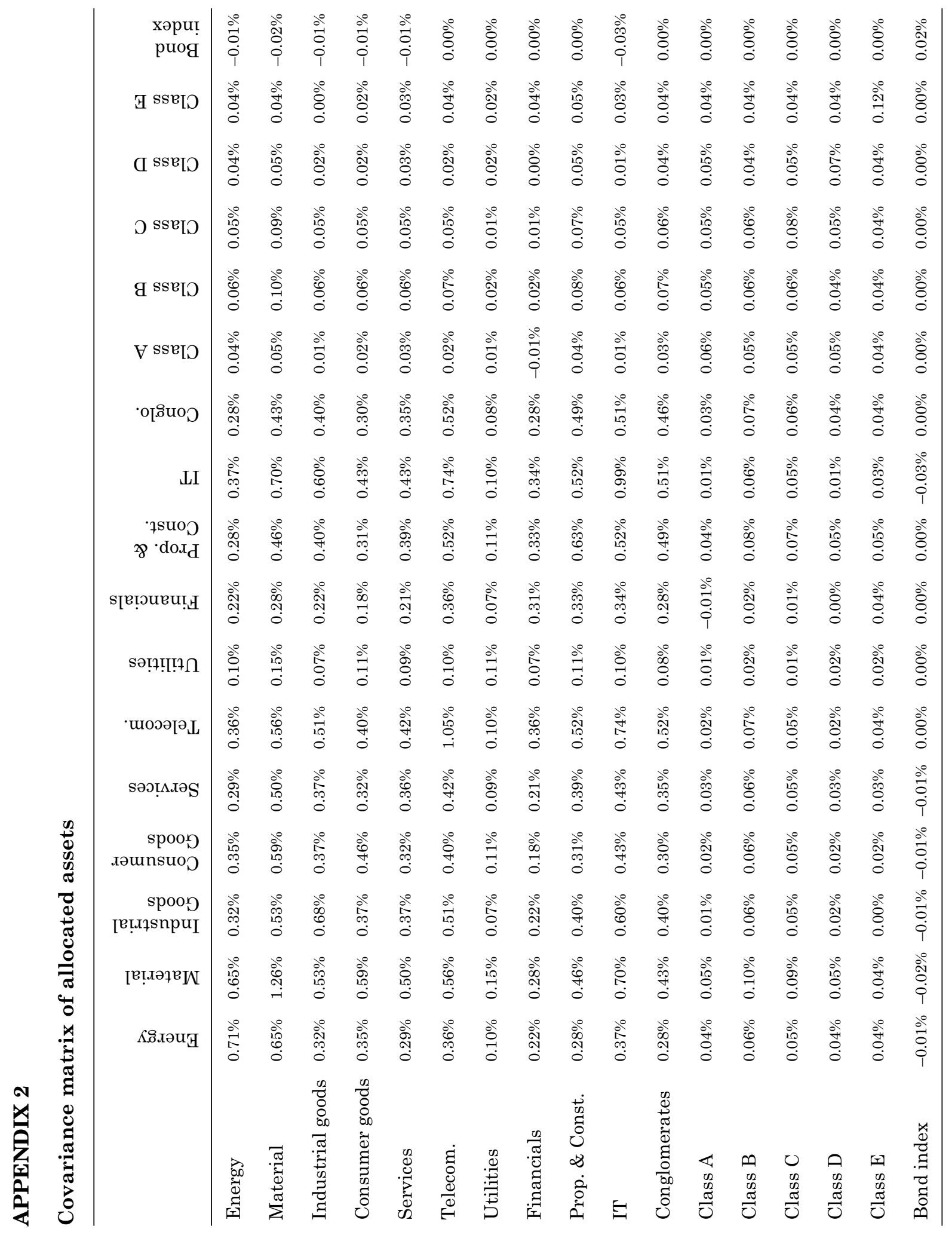

